\title{
Company Standard
}

National Cancer Institute

\section{Source}

National Cancer Institute. Company Standard. NCI Thesaurus. Code C134009.

A trademarked, copyrighted standard belonging to an organization. 